\title{
Originals
}

\section{Effects of two 5-hydroxytryptamine agonists on head-weaving behaviour in streptozotocin-diabetic mice}

\author{
E. Fujii, T. Nomoto and T. Muraki \\ Department of Pharmacology, Tokyo Women's Medical College, Tokyo, Japan
}

\begin{abstract}
Summary. The potencies of 5-methoxy-N, N-dimethyltryptamine (central 5-hydroxytryptamine 1 receptor agonist) and 8-hydroxy-2-(di-n-propylamino) tetralin (central 5-hydroxytryptamine $1 \mathrm{~A}$ receptor agonist) in eliciting head-weaving behaviour were studied in streptozotocin-diabetic mice and a group of control animals. Both drugs induced head-weaving behaviour in the streptozotocin-diabetic mice and control animals, but the potencies of these 5-hydroxytryptamine 1 agonists were reduced in the streptozotocin-diabetic mice. The numbers of head weaves elicited in the streptozotocindiabetic and control animals by the two drugs were suppressed by pre-treatment with propranolol (5-hydroxytryptamine $1 \mathrm{~A}$ receptor antagonist) and methysergide (5hydroxytryptamine 1 and 2 receptor antagonist), but not by ketanserin (5-hydroxytryptamine 2 receptor antagonist),
\end{abstract}

confirming the involvement of the $5-\mathrm{HT}_{\mathrm{IA}}$ receptor. Pretreatment with nicotinamide before administering streptozotocin prevented streptozotocin-induced hyperglycaemia and restored the inhibition of head-weaving behaviour observed in streptozotocin-diabetic mice. Insulin injection, which partially prevented streptozotocin-induced hyperglycaemia, completely prevented reduction of the number of head weaves elicited by 5 -methoxy- $\mathrm{N}, \mathrm{N}$-dimethyltryptamine in streptozotocin-diabetic mice. These results suggest that the reduced response to $5-\mathrm{HT}_{1}$ agonists in streptozotocindiabetic mice may be caused by the depletion of insulin.

Key words: 5-MeODMT, 8-OH-DPAT, head-weaving behaviour, $5-\mathrm{HT}_{1 \mathrm{~A}}$ receptors, $\mathrm{STZ}$, diabetic mice.
We have previously reported that responses to centrally acting drugs, such as morphine, pentobarbital and ketamine, may be altered in streptozotocin (STZ)-diabetic mice [1-4]. It has been reported that after administration of 5-HT agonists, rats showed signs of the 5-HT behavioural syndrome, such as resting tremours, rigidity, reciprocal forepaw treading, Straub tail, hindlimb abduction and side-to-side movements of the head (head weaving) [5]. Many studies have been carried out on the 5-hydroxytryptamine $1\left(5-\mathrm{HT}_{1}\right)$ receptor-mediated responses elicited by administering 5-methoxy- $\mathrm{N}, \mathrm{N}$-dimethyltryptamine (5MeODMT) and 8-hydroxy-2-(di-n-propylamino) tetralin (8-OH-DPAT) in rats [6-10], but few in mice [11-15]. Thus, it is unknown whether the $5-\mathrm{HT}_{1}$ receptor-mediated behaviour can be altered in STZ-diabetic mice. Therefore, we studied whether the 5-HT syndrome induced by 5-MeODMT and 8-OH-DPAT differs between STZdiabetic mice and control animals. We chose the headweaving behaviour as the 5 -HT behavioural syndrome because a preliminary study showed head-weaving to be the most conspicuous sign of the behavioural 5-HT syndrome in mice. To elucidate the role of insulin, we studied the ef- fects of nicotinamide (NicA) and insulin treatment on the head-weaving behaviour elicited by 5-MeODMT and 8$\mathrm{OH}-\mathrm{DPAT}$ in STZ-diabetic mice.

\section{Materials and methods}

Experimental animals

Male ddY mice (25-30 g) were housed in an air-conditioned room (temperature $22 \pm 2^{\circ} \mathrm{C}$, humidity $55 \pm 5 \%$ ) with a controlled lightdark cycle (light on $06.00-20.00$ hours) and freely available food and water. To induce diabetes, STZ $(170 \mathrm{mg} / \mathrm{kg})$, freshly dissolved in $0.1 \mathrm{~mol} / \mathrm{I}$ citrate buffer ( $\mathrm{pH} 4.6$ ), was injected i. p. in the mice 2 weeks before the experiment. The control animals received citrate buffer i.p. instead of STZ. Two weeks later, the STZ-treated mice showed signs of diabetes such as reduced growth rate, glucosuria and hyperglycaemia. NicA (500 mg/kg, i.p.) was administered $15 \mathrm{~min}$ before STZ. Some STZ-diabetic mice were injected with a daily dose of $10 \mathrm{IU} / \mathrm{kg}$ of Isophane (NPH)-insulin for 3 days from the eleventh day following STZ injection. The NPH-insulin was injected s. c. twice a day, once in the morning and once in the evening at different body sites [3]. Experiments were performed about $20 \mathrm{~h}$ after the last insulin injection. 
Table 1. Changes in body weight and serum glucose level in streptozotocin (STZ), nicotinamide (NicA)-STZ and STZ-insulin treated mice and control animals

\begin{tabular}{|c|c|c|c|c|}
\hline & & \multicolumn{2}{|c|}{$\begin{array}{l}\text { Body weight } \\
\text { (g) }\end{array}$} & \multirow[t]{2}{*}{$\begin{array}{l}\text { Serum glucose } \\
(\mathrm{mmol} / \mathrm{l})\end{array}$} \\
\hline & & Initial & Final & \\
\hline Control & (11) & $31.4 \pm 0.39$ & $36.6 \pm 0.77$ & $8.4 \pm 0.44$ \\
\hline STZ & (14) & $31.8 \pm 0.25$ & $32.3 \pm 0.75^{\mathrm{a}}$ & $33.3 \pm 2.16^{\mathrm{a}}$ \\
\hline NicA-STZ & (10) & $31.4 \pm 0.37$ & $36.3 \pm 0.49$ & $7.7 \pm 0.55^{\mathrm{b}}$ \\
\hline STZ-insulin & (19) & $31.9 \pm 0.39$ & $32.9 \pm 0.54^{\mathrm{a}}$ & $24.3 \pm 0.33^{\mathrm{a}, \mathrm{b}}$ \\
\hline
\end{tabular}

$\mathrm{STZ}(170 \mathrm{mg} / \mathrm{kg})$ was injected i.p. in 6-week-old mice 2 weeks before killing (STZ group). The control animals received i. p. injections of citrate buffer instead of STZ. NicA $(500 \mathrm{mg} / \mathrm{kg}$, i. p.) was administered $15 \mathrm{~min}$ before administering STZ (NicA-STZ group), A daily dose of $10 \mathrm{IU}$ NPH-insulin $/ \mathrm{kg}$ was s. c. injected for 3 days from the eleventh day of the STZ injection (STZ-insulin group). The mice were weighed when the STZ or citrate buffer (initial) was administered and 2 weeks later (final) when the mice were killed, and the serum glucose was measured. Values represent the mean \pm SEM. Numbers in parenthesis indicate the number of mice. ${ }^{\mathrm{a}} p<0.01 \mathrm{vs}$ control animals, ${ }^{\circ} p<0.01$ vs STZ-diabetic mice (Student's $t$-test).

Blood, collected when the mice were killed, was used for glucose determination by the o-toluidine-boric acid method using a glucose test kit (Wako, Tokyo, Japan) [3].

\section{Behavioural observations}

Mice were placed in individual plastic cages and the numbers of head weaves were counted after i.p. injection of 5-MeODMT or $8-\mathrm{OH}$ DPAT. The appearance of head weaving was observed for $20 \mathrm{~min}$ after administering 5-MeODMT. Two-minute observation sessions were repeated every $5 \mathrm{~min}$ for $20 \mathrm{~min}$ and the sum of the head weaves occurring in the four sessions was taken as the total number of head weaves. In the case of 8-OH-DPAT, the most head weaves occurred within $7 \mathrm{~min}$, therefore we counted the number of head weaves for 7 min after administering 8-OH-DPAT as the total number for 8-OH-DPAT unless otherwise stated.

\section{Drugs and treatment}

Propranolol and ketanserin were administered i.p. $15 \mathrm{~min}$ before, and methysergide was administered i. p. 5 min before administration of 5-MeODMT or 8-OH-DPAT.

The sources of the drugs used are as follows: STZ and 5-MeODMT (Sigma Chemical Co., Mo, USA), 8-OH-DPAT (8-OHDPAT HBr, Research Biochemicals Inc., Mass., USA). NicA (Tokyo Kasei Kogyo Co., Tokyo, Japan), NPH-insulin (NPH-ISZILIN, $40 \mathrm{IU} / \mathrm{ml}$, Shimizu Pharmaceutical Co., Shizuoka, Japan), methysergide (Sandoz Pharmaceuticals, Feltham, UK), propranolol (Inderal, Sumitomo Pharmaceutical Co., Osaka, Japan) and ketanserin tartrate (Janssen Kyowa, Tokyo, Japan).5-MeODMT was suspended in $0.5 \%$ carboxymethylcellulose-Na. Methysergide was dissolved in several drops of methanesulphonic acid and diluted in $154 \mathrm{mmol} / \mathrm{l}$ $\mathrm{NaCl}$. Other drugs were dissolved in $154 \mathrm{mmol} / \mathrm{l} \mathrm{NaCl}$. All drugs were administered to the mice in dosages of $0.1 \mathrm{ml} / 10 \mathrm{~g}$ body weight.

\section{Statistical analysis}

Results are expressed as mean \pm SEM and were statistically evaluated by Student's $t$-test.

\section{Results}

Changes in body weight and serum glucose in STZ, NicA-STZ and NPH-insulin treated STZ-diabetic (STZ-insulin) mice and control animals

Body weight increases were reduced by STZ treatment $(p<0.01)$ and the mean serum glucose level was $33.3 \pm 2.16 \mathrm{mmol} / \mathrm{l}$ in STZ-diabetic mice, which was higher than that in the control animals (Table 1). Pre-treatment with NicA completely prevented body-weight reductions and STZ-induced hyperglycaemia. Insulin did not affect body-weight reductions in STZ-diabetic mice, but significantly prevented STZ-induced hyperglycaemia, although the serum glucose levels in STZ-insulin treated mice were higher than in the control animals.

\section{Effects of 5-MeODMTon head-weaving behaviour in STZ, NicA-STZ and STZ-insulin treated mice and control animals}

The head-weaving behaviour elicited by $6-10 \mathrm{mg} / \mathrm{kg}$ doses of 5-MeODMT in STZ-diabetic mice and control animals was dose-dependent. 5-MeODMT also induced resting tremours in the STZ-diabetic mice and control animals, but we did not study resting tremours in this experiment. The total number of head weaves was lower in the STZ-diabetic mice than in the control animals (Fig. 1). Figure $2 \mathrm{a}$ and $\mathrm{b}$ shows the time course for the number of head weaves in each 2 -min observation session and the total number of head weaves elicited in STZ, NicA-STZ and STZ-insulin treated mice and control animals by 5 -MeODMT $(10 \mathrm{mg} / \mathrm{kg})$. The number of head weaves peaked in all mice groups 10 to $12 \mathrm{~min}$ after administering 5-MeODMT, however, the peak effect of 5-MeODMT was again less in the STZ-diabetic mice than in the control animals. NicA pre-treatment or insulin treatment almost completely prevented the reduction in the head weaves elicited in STZ-diabetic mice by 5-MeODMT.

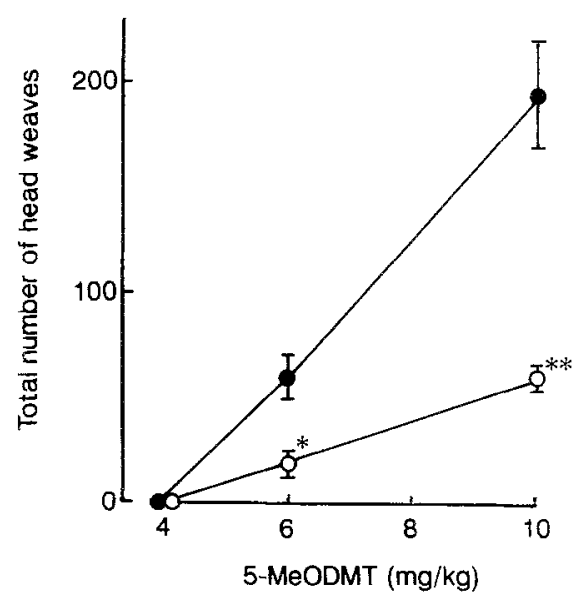

Fig. 1. Effects of increasing doses of 5-methoxy-N, N-dimethyltryptamine (5-MeODMT) on the total number of head weaves in STZdiabetic $(\bigcirc)$ mice and controls $(\bigcirc)$. Values represent the mean \pm SEM $(n=10) . * p<0.05, * * p<0.01$ vs control animals 

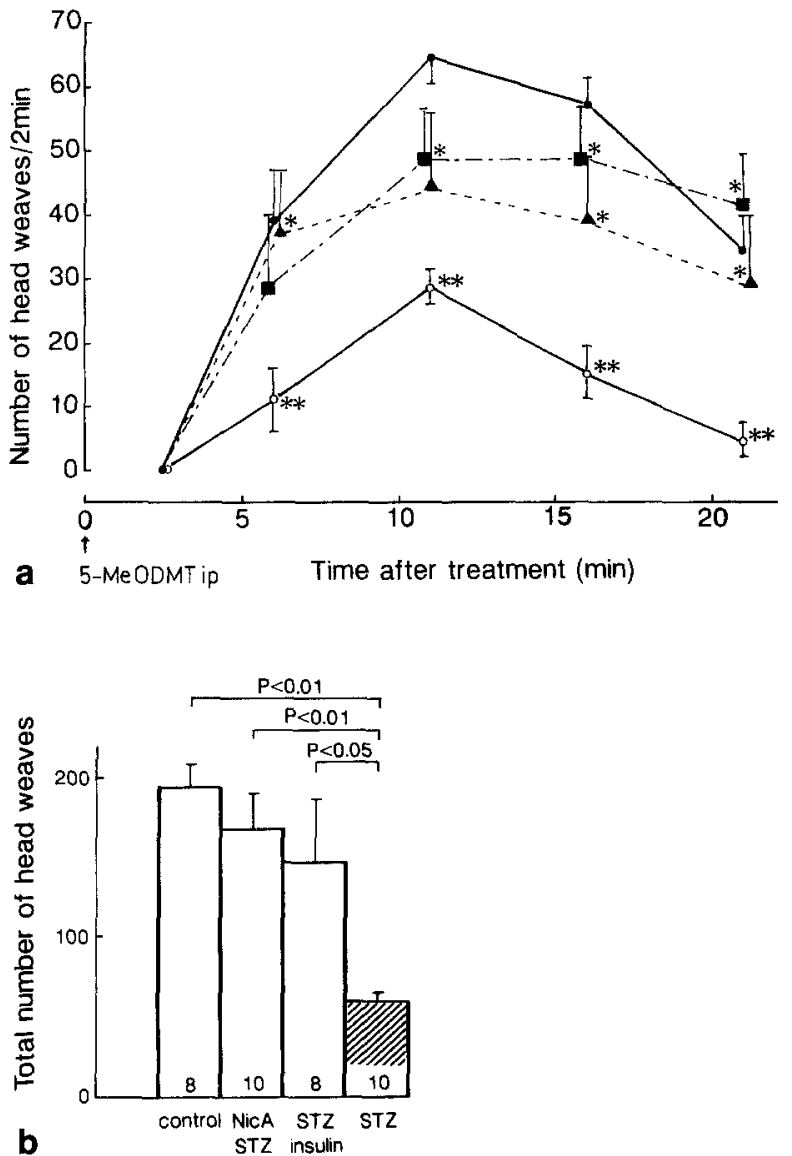

Fig. 2a,b. Time course of the effect of 5-MeODMT (10 mg/kg, i.p.) on the number of head weaves (a) and total number of head weaves elicited by 5-MeODMT (10 mg/kg, i.p.) (b) in STZ (O), NicA-STZ (a) and STZ-insulin ( $\Delta$ ) treated mice and control animals (O). Treatment of mice was the same as for those listed in Table 1. Values represent the mean $\pm \operatorname{SEM}(n=10)$. ${ }^{* *} p<0.01$ vs control animals, * $p<0.05$ vs STZ-diabetic mice

To show the subtype of 5-HT receptors involved in eliciting the head-weaving behaviour, we examined the effects of three 5-HT receptor antagonists on the 5-MeODMT-induced head-weaving behaviour. The basal number of head weaves by STZ-diabetic mice $(60 \pm 6, n=10)$ significantly differed from that of the control animals $(195 \pm 13, n=10)$. Pre-treatment with propranolol $(20-40 \mathrm{mg} / \mathrm{kg})$ increased mortality only in the 5-MeODMT-treated control animals when administered 5 min previously (data not shown), but propranolol $(40 \mathrm{mg} / \mathrm{kg})$ administered $15 \mathrm{~min}$ before the 5-MeODMT significantly reduced the number of head weaves in the STZ-diabetic mice and control animals without killing the mice (Fig.3). Methysergide $(10 \mathrm{mg} / \mathrm{kg})$ reduced the number of head weaves in the STZ-diabetic and control animals, with the reduction being lower in the STZ-diabetic mice than in the control animals. Ketanserin $(0.5 \mathrm{mg} / \mathrm{kg})$ did not affect the headweaving behaviour elicited by 5-MeODMT in either the STZ-diabetic mice or control animals. These results suggest that the head-weaving behaviour elicited by 5-MeODMT may be mediated by the postsynaptic $5-\mathrm{HT}_{1 \mathrm{~A}}$ receptor.

\section{Effects of 8-OH-DPAT on head-weaving behaviour in STZ-diabetic mice and control animals}

After administering 8-OH-DPAT, the 5-HT syndrome, including resting tremours, hyperactivity, Straub tail and head weaving, was evident in the mice. 8-OH-DPAT induced a short clonic seizure within $7 \mathrm{~min}$, immediately followed by the head-weaving behaviour. The maximum head-weaving rate was observed within $7 \mathrm{~min}$ of administering 8-OH-DPAT, and the head-weaving behaviour ceased within $15 \mathrm{~min}$. Figure $4 \mathrm{a}$ and $\mathrm{b}$ show the time course for the number of head weaves elicited in STZdiabetic and control animals by 40 and $60 \mathrm{mg} / \mathrm{kg}$ doses of 8 -OH-DPAT. The $40 \mathrm{mg} / \mathrm{kg}$ dose of 8 -OH-DPAT induced head-weaving behaviour in the control animals, with the peak effect observed 5 to $7 \mathrm{~min}$ after administering 8-OH-DPAT, but this dose did not induce head-weav ing behaviour in the STZ-diabetic mice (Fig.4a). A higher dose of 8-OH-DPAT $(60 \mathrm{mg} / \mathrm{kg})$ elicited headweaving behaviour in the STZ-diabetic mice, but not in the control animals. Figure 5 shows the dose-dependent effects of 8-OH-DPAT in inducing head-weaving behaviour in STZ-diabetic and control animals. The dose response curve is bell-shaped, indicating that a higher dose of 8-OH-DPAT inhibited the head-weaving behaviour. The peak effect dose of 8-OH-DPAT for eliciting headweaving behaviour in STZ-diabetic mice $(60 \mathrm{mg} / \mathrm{kg})$ was larger than that for the control animals which have been $(40 \mathrm{mg} / \mathrm{kg})$. A larger dose $(60 \mathrm{mg} / \mathrm{kg}$ or more $)$ of $8-\mathrm{OH}-$ DPAT induced generalized convulsions and death in some control animals which have been excluded from the experiment. The dose response curve for $8-\mathrm{OH}-$ DPAT shifted to the right in STZ-diabetic mice, indicating reduced sensitivity of STZ-treated mice to $8-\mathrm{OH}$ DPAT.



Fig.3. Effects of 5-HT antagonists on the total number of head weaves elicited in STZ-diabetic mice and control animals by 5-MeODMT. Values ( $\%$ of total number of head weaves of mice without antagonists) represent the mean \pm SEM ( $n=6-11)$. STZdiabetic ( $\square$ ) mice and control animals $(\square)$ received $10 \mathrm{mg} / \mathrm{kg}$ doses of 5-MeODMT. Propranolol ( $40 \mathrm{mg} / \mathrm{kg}$, i.p.) and ketanserin $(0.5 \mathrm{mg} / \mathrm{kg}$, i. p. $)$ were administered $15 \mathrm{~min}$ before, and methysergide $(10 \mathrm{mg} / \mathrm{kg}$, i.p.) was administered $5 \mathrm{~min}$ before administering 5-MeODMT. The effects of 5-HT antagonists are expressed as \% of the total number of head weaves of STZ-diabetic mice $(60 \pm 6$, $n=10)$ and control animals $(195 \pm 13, n=10)$ treated with $154 \mathrm{mmol} / 1 \mathrm{NaCl}$ instead of $5-\mathrm{HT}$ antagonists. $* p<0.05$, ** $p<0.01$ vs $154 \mathrm{mmol} / \mathrm{l} \mathrm{NaCl}$ treated STZ-diabetic mice or control animals. ${ }^{+} p<0.05$ vs control animals 

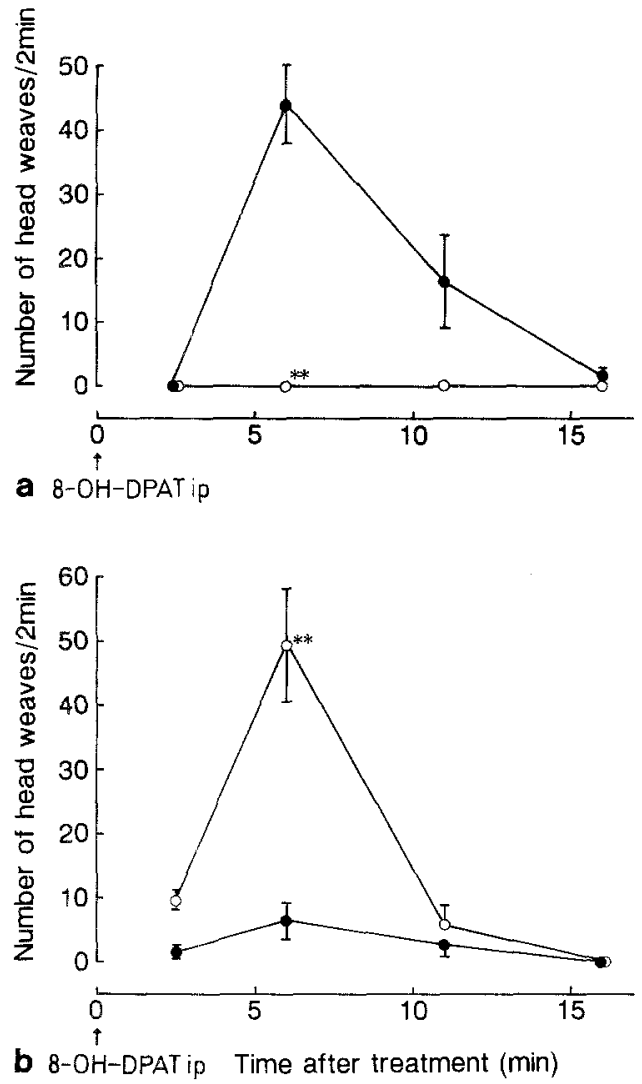

Fig. 4 a,b. Time course of the number of head weaves elicited by $40 \mathrm{mg} / \mathrm{kg}$, i.p. (a) and $60 \mathrm{mg} / \mathrm{kg}$, i.p. (b) doses of 8-OH-DPAT in STZ-diabetic (O) mice and control animals $(O)$. Values represent the mean $\pm \operatorname{SEM}(n=10)$. ${ }^{*} p<0.01$ vs control animals

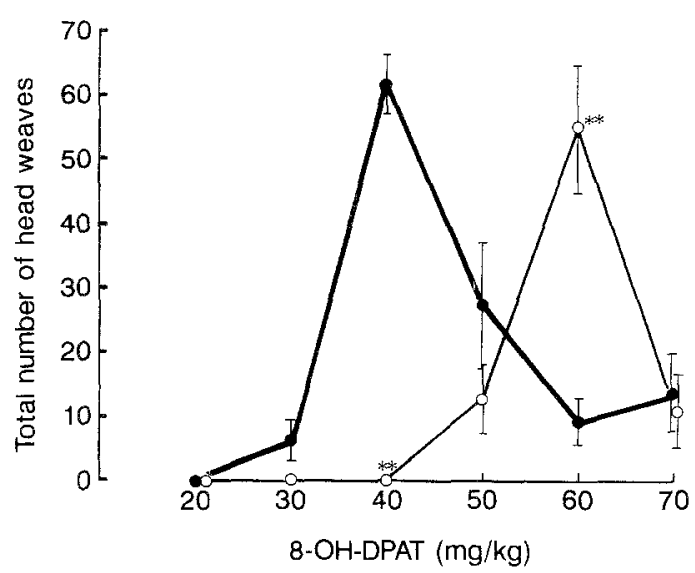

Fig.5. Effects of the dose of 8-OH-DPAT on the total number of head weaves in STZ-diabetic $(O)$ mice and control animals ( $O$ ) Values represent the mean $\pm \operatorname{SEM}(n=10)$. ${ }^{* *} p<0.01$ vs control animals

Similar to the results with 5-MeODMT, Figure 6 shows that the total number of head weaves elicited in STZdiabetic mice $(47 \pm 6, n=10)$ and the control animals $(59 \pm 10, n=10)$ by 8 -OH-DPAT is reduced by pre-treatment with propranolol $(1 \mathrm{mg} / \mathrm{kg})$ and methysergide $(10 \mathrm{mg} / \mathrm{kg})$, but not by ketanserin $(0.5 \mathrm{mg} / \mathrm{kg})$, which again suggests the involvement of the $5-\mathrm{HT}_{1 \mathrm{~A}}$ receptor in the STZ-diabetic and control animals.

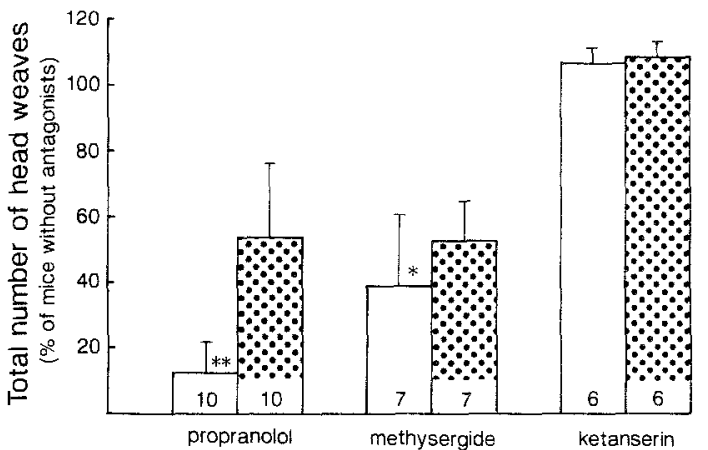

Fig.6. Effects of 5-HT antagonists on the total number of head weaves elicited in STZ-diabetic mice and control animals by 8-OHDPAT. Values (\% of total number of head weaves of mice without antagonists) represent the mean $\pm \operatorname{SEM}(n=6-10)$. Control animals $(\square)$ and STZ-diabetic mice (粦) respectively received $40 \mathrm{mg} / \mathrm{kg}$ and $60 \mathrm{mg} / \mathrm{kg}$ doses of 8-OH-DPAT. Propranolol $(1 \mathrm{mg} / \mathrm{kg}, \mathrm{i} . \mathrm{p}$.) and ketanserin $(0.5 \mathrm{mg} / \mathrm{kg}$, i.p.) were administered $15 \mathrm{~min}$ before, and methysergide $(10 \mathrm{mg} / \mathrm{kg}$, i.p.) was administered $5 \mathrm{~min}$ before administering 8-OH-DPAT. The effects of 5-HT antagonists are expressed as \% of the total number of head weaves of control animals $(59 \pm 10$, $n=10)$ and STZ-diabetic mice $(47 \pm 6, n=10)$ treated with $154 \mathrm{mmol} / 1 \mathrm{NaCl}$ instead of $5-\mathrm{HT}$ antagonists. * $p<0.05$, ** $p<0.01$ vs $154 \mathrm{mmol} / \mathrm{l} \mathrm{NaCl}$-treated control animals

\section{Discussion}

We observed that head-weaving behaviour elicited in normal ddY strain mice by 5-MeODMT and 8-OH-DPAT is dose-dependent and that the head-weaving behaviour is prevented by propranolol and methysergide, but not by ketanserin. These results confirm previous studies showing that 5-MeODMT and 8-OH-DPAT induces head-weaving behaviour in rats and normal mice of other strains by activating the central 5- $\mathrm{HT}_{1 \mathrm{~A}}$ receptor $[5-11,14,15]$.

Previous studies show that s.c. and i.p. injections of lower doses (around $0.1 \mathrm{mg} / \mathrm{kg}$ ) of 8-OH-DPAT can induce the 5-HT syndrome in rats $[9,10]$. Goodwin and Green [11] reported that 8-OH-DPAT $(10 \mathrm{mg} / \mathrm{kg}$, s.c.) does not induce the 5-HT syndrome in C57BL mice. However, Yamada et al. [15] reported that in doses exceeding $20 \mathrm{mg} / \mathrm{kg}$, i.p., 8-OH-DPAT induces mild, short-duration 5-HT syndrome in C57BL mice and suggested a species difference in the sensitivity to 8-OH-DPAT between rats and mice. In agreement with previous studies on mice, we found that 8 -OH-DPAT $(20-70 \mathrm{mg} / \mathrm{kg}$, i.p.) induces the head-weaving behaviour in ddY mice, and we consider that for some unknown reason this mouse strain is particularly insensitive to 8-OH-DPAT.

Previous workers have not reported the inhibition of head weaving by large doses of 8-OH-DPAT, probably because they have not studied the effects of an 8-OH-DPAT dose as high as $40 \mathrm{mg} / \mathrm{kg}$. (We did not study whether high doses of 5-MeODMT inhibit head weaving either.) The mechanism of head-weaving-behaviour inhibition by high doses of 8-OH-DPAT is unclear at present.

We proved that STZ-induced diabetic mice are hyposensitive to 5-MeODMT and 8-OH-DPAT in eliciting head-weaving behaviour, although the difference between STZ-diabetic mice and control animals is only quantitative. The mechanism of STZ-induced hyposensi- 
tivity to $5-\mathrm{HT}_{1 \mathrm{~A}}$ agonists is unknown at present. Trulson and MacKenzie [16] reported that there are no significant changes in specific $\left[{ }^{3} \mathrm{H}\right]-5-\mathrm{HT}$ receptor binding in the brains of STZ-diabetic rats compared with control values, however, the regional distribution pattern of the 5-HT receptor in the brains of STZ-diabetic mice may differ from that of normal mice. There are several possible causes for the hyposensitivity of STZ-diabetic mice to 5$\mathrm{HT}_{1 \mathrm{~A}}$ agonists, namely, the penetration rate into the brain of injected 5-HT 1 agonists may be affected by STZ pretreatment or hyperglycaemia or abnormal pentose metabolism in STZ-diabetic mice may indirectly affect the responsiveness of the brain to $5-\mathrm{HT}_{1 \mathrm{~A}}$ agonists. It is also unknown whether diabetes reduces the uptake of 5 MeODMT or 8-OH-DPAT by the brain.

To elucidate the role of insulin in the hyposensitivity of STZ-diabetic mice to 5-MeODMT and 8-OH-DPAT, we studied whether the effects of STZ are prevented by insulin and NicA. NicA, an inhibitor of poly (ADP-ribose) synthetase, maintains the intracellular level of NAD, thereby preventing the selective cytotoxicity of STZ on pancreatic Beta cells [17]. In this study, NicA completely and insulin partially prevented hyperglycaemia in STZdiabetic mice, and NicA and insulin completely recovered the effect of STZ treatment in reducing the number of head weaves elicited by 5-MeODMT. Although we did not study whether NicA and insulin reduce the effect of 8-OH-DPAT in inducing head-weaving behaviour in STZ-diabetic mice, the results suggest that the depletion of insulin may have a causal relationship with the hyposensitivity of STZ-diabetic mice to 5 - $\mathrm{HT}_{1 \mathrm{~A}}$ agonists.

This study proves that 5-MeODMT and 8-OH-DPAT induce head-weaving behaviour in STZ-diabetic mice and control animals through the $5-\mathrm{HT}_{1 \mathrm{~A}}$ receptor, however, the 5-HT responses of the STZ-diabetic mice were less than those of normal mice, indicating the hyposensitivity of STZ-diabetic mice to 5-HT $1 \mathrm{~A}$ agonists. The clinical importance of the reduced 5-HT syndrome in STZ-diabetic mice is unknown. However, this study suggests that the pharmacological effects of 5-HT agonists or antagonists in diabetic patients may differ from that in normal man.

Acknowledgements. The ketanserin tartrate used in this study was donated by Janssen Kyowa Company, Tokyo, Japan.

\section{References}

1. Fujii E, Nomoto T, Tsukahara F et al. (1983) Antinociceptive potency of morphine in streptozotocin-diabetic mice. Tokyo Women's Med Coll 53: 1039-1045 (Abstract)

2. Fujii E, Tsukahara F, Nomoto T (1984) Influences of drugs in streptozotocin (STZ)-diabetic mice (III): alterations in the sensitivity to ketamine anesthesia and anticociceptive potency of thalamonal. Jpn J Pharmacol 36 [Suppl.]: 334
3. Fujii E, Tsukahara F, Nomoto T (1987) Changes in pentobarbital hypnosis and hepatic metabolism in streptozotocin-diabetic mice. Folia Pharmacol Japon 90: 83-89

4. Fujii E, Nomoto T (1987) Influences of drugs in streptozotocin (STZ)-diabetic mice (V): Anticonvulsant activity of ketamine on pentylenetetrazol (PTZ)-induced seizures. Jpn J Pharmacol 43 [Suppl.] 230

5. Jacobs BL (1976) An animal behavior model for studying central serotonergic synapses. Life Scie 19:777-786

6. Hjorth S, Carlsson A, Lindberg P et al. (1982) 8-Hydroxy-2-(din-propylamino) tetralin, 8-OH-DPAT, a potent and selective simplified ergot congener with central 5-HT-receptor stimulating activity. J Neural Transm 55: 169-188

7. Lucki I, Nobler MS, Frazer A (1984) Differential actions of serotonin antagonists on two behavioral models of serotonin receptor activation in the rat. J Pharmacol Exp Ther 228: 133-139

8. Tricklebank MD, Forler C, Middlemiss DN, Fozard JR (1985) Subtypes of the 5-HT receptor mediating the behavioural responses to 5-methoxy-N, N-dimethyltryptamine in the rat. Eur $\mathrm{J}$ Pharmacol 117: 15-24

9. Tricklebank MD, Forler C, Fozard JR (1985) The involvement of subtypes of the 5- $\mathrm{HT}_{1}$ receptor and of catecholaminergic systems in the behavioural response to 8 -hydroxy-2-(di-n-propylamino) tetralin in the rat. Eur J Pharmacol 106: 271-282

10. Smith LM, Peroutka SJ (1986) Differential effects of 5-hydroxytryptamine $_{\mathrm{IA}}$ selective drugs on the 5-HT behavioral syndrome. Pharmacol Biochem Behav 24: 1513-1519

11. Goodwin GM, Green AR (1985) A behavioural and biochemical study in mice and rats of putative selective agonists and antagonists for 5- $\mathrm{HT}_{1}$ and 5- $\mathrm{HT}_{2}$ receptors. Br J Pharmacol 84: 743753

12. De Souza RJ, Goodwin GM, Green AR, Heal DJ (1986) Effect of chronic treatment with 5-HT 1 agonist (8-OH-DPAT and RU24969) and antagonist (ipsapirone) drugs on the behavioural responses of mice to $5-\mathrm{HT}_{1}$ agonist and $5-\mathrm{HT}_{2}$ agonists. $\mathrm{Br} \mathrm{J}$ Pharmacol 89: 377-384

13. Nabeshima T, Ishikawa K, Yamaguchi K, Furukawa H, Kameyama T (1987) Phencyclidine-induced head-weaving observed in mice after ritanserin treatment. Eur J Pharmacol 139 $171-178$

14. Sugimoto Y, Yamada J, Horisaka K (1988) Behavioural effects of 5-HT-1A receptor agonists in mice. Jpn J Pharmacol 46 [Suppl.]: 172

15. Yamada J, Sugimoto Y, Horisaka K (1988) The behavioural effects of 8-hydroxy-2-(di-n-propylamino) tetralin (8-OH-DPAT) in mice. Eur J Pharmacol 154:299-304

16. Trulson ME, MacKenzie RG (1981) Subsensitivity to 5-hydroxytryptamine in agonists occurs in streptozotocin-diabetic rats with no change in $\left[{ }^{3} \mathrm{H}\right]-5 \mathrm{HT}$ receptor binding. J Pharm Parmacol 33: $472-474$

17. Okamoto $H$ (1981) Regulation of proinsulin synthesis in pancreatic islets and a new aspect to insulin-dependent diabetes. Mol Cell Biochem 37: 43-61

Received: 8 November 1990

and in revised form: 5 April 1991

Dr. E. Fujii

Department of Pharmacology

Tokyo Women's Medical College

8-1 Kawada-cho

Shinjuku-ku

Tokyo 162

Japan. 